University of Rhode Island

DigitalCommons@URI

The Rhode Island Current Conditions Index

Economics

6-2017

\title{
Rhode Island Current Conditions Index -- June 2017
}

Leonard Lardaro

University of Rhode Island, lardaro@uri.edu

Follow this and additional works at: https://digitalcommons.uri.edu/ricci

Part of the Econometrics Commons

Terms of Use

All rights reserved under copyright.

\section{Recommended Citation}

Lardaro, Leonard, "Rhode Island Current Conditions Index -- June 2017" (2017). The Rhode Island Current Conditions Index. Paper 162.

https://digitalcommons.uri.edu/ricci/162

This Article is brought to you for free and open access by the Economics at DigitalCommons@URI. It has been accepted for inclusion in The Rhode Island Current Conditions Index by an authorized administrator of DigitalCommons@URI.For more information, please contact digitalcommons-group@uri.edu. 


\title{
CURRENT CONDITIONS
}

\section{LEONARD LARDARO, URI}

\author{
Available Online: http:/ / www.llardaro.com/ current.htm \\ Blog: http:/ / rieconomy.blogspot.com \\ Twitter: @ladardo
}

VOL XXIV

NUMBER 7

JUN 2017
The first half of 2017 is now on the books. Overall, our state's economic performance so far this year appears to have been quite favorable, in terms of our gaining then sustaining economic momentum following a very disappointing 2016. The real GDP data from which growth rates are derived, however, show that the favorable momentum we experienced in the first half of 2017, while welcome, is not necessarily cause for celebration - yet. Looking at growth rates of the Rhode Island economy last year, Rhode Island had a 5 percent rate of growth in Q2 of 2016. Quite impressive, right? Not necessarily. When evaluating growth rates it is necessary to first ask the question relative to when? GDP growth rates are sequential: they evaluate the value of the most recent quarter relative to that of the prior quarter. What was Rhode Island's growth rate in Q1 of 2016? Ready for this? Our Q1 2016 growth was -4.4 percent. So, 5 percent growth in Q2 last year following a decline of 4.4 percent the prior quarter means that at the end of the first half of 2016, real GDP for Rhode Island was virtually unchanged from its value at the end of 2015. High $\mathrm{CCl}$ values during the first half of 2017 thus reflect acceleration from a flat economy in the first half of 2016 , values not very hard to beat. This is my latest attempt to explain readings from a

\begin{tabular}{|l|r|r|}
\hline \multicolumn{3}{|c|}{ CCI Indicators - \% Change } \\
\hline Government Employment & 0.0 & \\
\hline US Consumer Sentiment & 1.8 & Y \\
\hline Single-Unit Permits & 30.1 & Y \\
\hline Retail Sales & 4.5 & Y \\
\hline Employment Services Jobs & -0.8 & \\
\hline Priv. Serv-Prod Employment & 1.0 & Y \\
\hline Total Manufacturing Hours & 2.5 & Y \\
\hline Manufacturing Wage & 4.1 & Y \\
\hline Labor Force & 0.7 & Y \\
\hline Benefit Exhaustions & -2.5 & Y \\
\hline New Claims & -3.9 & Y \\
\hline Unemployment Rate (change) & -1.2 & Y \\
\hline \multicolumn{2}{|c|}{ Y = Improved Value } \\
\hline
\end{tabular}

momentum indicator like the $\mathrm{CCl}$. We are not back to normal times yet. That will require sustained upward momentum, for us, gained largely from both the US and Massachusetts economies.

The Current Conditions Index for June was 83, as ten of the twelve indicators (83.3\%) improved. As stated earlier, the higher $\mathrm{CCl}$ values we have been experiencing represent a sustained acceleration compared to last year, although the second quarter values last year weren't that difficult to beat. Happily, we have now beat last year's CCI value for each of the six months of 2017 which is an exceptionally rare accomplishment here. Better yet, assuming the employment data hold up, in May Rhode Island finally moved past its prior payroll employment peak.

Of the five leading indicators contained in the $\mathrm{CCl}$, four improved in June. All of these had relatively easy comps from a year ago. The sole indicator that failed to improve reflects future hiring and

layoffs. Employment Service Jobs, which includes temporary employment and is a leading indictor of future employment, failed to improve yet again, declining by 0.8 percent in June. Its downtrend continues to be cause for concern.

Fortunately, New Claims, the timeliest measure of layoffs, fell in June $(-3.9 \%)$, registering its sixth improvement in the last seven months. Along with this, both of the goods-producing leading indicators contained in the $\mathrm{CCl}$ improved. Single-Unit Permits which reflects new home construction, rose by 30.1 percent thanks to an easy comp last June, sustaining its uptrend. Total Manufacturing Hours, a proxy for manufacturing output, the other goods-producing indicator, rose by a robust 2.5 percent, as both manufacturing employment and the workweek rose. Finally, US Consumer Sentiment improved in June $(+1.8 \%)$, its eighth consecutive increase.

Government Employment remained unchanged from a year ago, thus failing to improve. It did, however, manage to remain above 60,000, which it has now done for over a year. Private Service-Producing Employment growth, which has been somewhat volatile of late, returned to the one percent level in June. Retail Sales did well again in June, rising by over 4 percent. Benefit Exhaustions, which reflects longer-term unemployment, fell yet again in June, sustaining its long-term downtrend. Finally, our Labor Force trend, the train wreck, improved again in June - four in a row. We can now say that for the fourth time in years, Rhode Island's Unemployment Rate fell (relative to a year ago) for the right reasons. It did, however, rise on a monthly basis.

LABOR FORCE

Participation Rate May 2016

$64.5 \%$

$61.0 \%$

Employment Rate

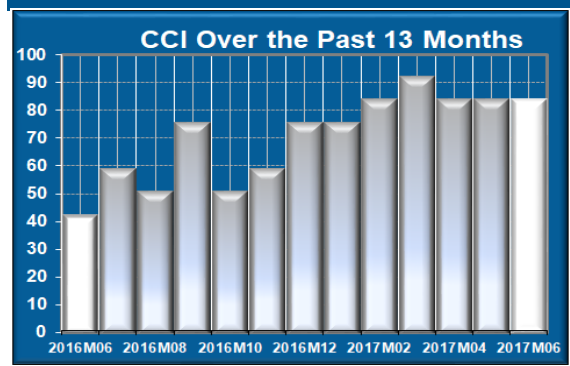

\section{THE BOTTOM LINE}

Rhode I sland has restored the momentum it experienced last year. The lingering aftereffects of the 2016 slowdown, notably disappointing tax revenue and rising case loads, which pose problems for fiscal choices, should begin to subside somewhat. The good news (or bad - you choose), is that a highly deficient state budget has now been passed. Sadly, the concept of investment-oriented spending remains far beyond RI government's comprehension.

\begin{tabular}{c|c|c|c|c|c|c|c|c|c|c|c|c|c|} 
& Jan & Feb & Mar & Apr & May & J un & Jul & Aug & Sep & Oct & Nov & Dec \\
\hline 2016 & $50 \downarrow$ & $58 \downarrow$ & $58 \uparrow$ & $33 \downarrow$ & 50 & 42 & $58 \downarrow$ & $50 \downarrow$ & 75 & $50 \downarrow$ & $58 \downarrow$ & $75 \downarrow$ \\
\hline 2017 & 75 & 83 & 92 & 83 & 83 & 83 & & & & & & \\
\hline
\end{tabular}

